\title{
Fish processing wastes for microbial enzyme production: a review
}

\author{
Faouzi Ben Rebah $\cdot$ Nabil Miled
}

Received: 23 April 2012/ Accepted: 16 October 2012/Published online: 30 October 2012

(C) The Author(s) 2012. This article is published with open access at Springerlink.com

\begin{abstract}
Fishery processing industries generate large amounts of by-products. The disposal of these wastes represents an increasing environmental and health problem. To avoid wasting these by-products, various disposal methods have been applied including, ensilation, fermentation, hydrolysate and fish oil production. Interestingly, fish byproducts provide an excellent nutrient source for microbial growth useful in enzyme production process, which is largely governed by the cost related to the growth media. Fish wastes (heads, viscera, chitinous material, wastewater, etc.) were prepared and tested as growth substrates for microbial enzymes production such as protease, lipase, chitinolytic and ligninolytic enzymes. This new approach described in this review can reduce environmental problems associated with waste disposal and, simultaneously, lower the cost of microbial enzyme production.
\end{abstract}

Keywords Fish waste - Growth media - Protease . Lipase $\cdot$ Chitinolytic enzymes $\cdot$ Ligninolytic enzymes

\section{Introduction}

In recent years, there has been a constant increase in the exploitation of fish resources and the estimated quantity used for human consumption (105.6 million tons) is globally $75 \%$ of the worldwide fish production. The remaining $25 \%$ of the catch (34.8 million tons) are considered as wastes (FAO 2007). Furthermore, the commercial fish processing industry generates large quantities of solid

F. Ben Rebah $(\bowtie) \cdot$ N. Miled

Laboratoire de Biochimie et de Génie Enzymatique des Lipases, ENIS, BPW 1173-3038 Sfax, Tunisia

e-mail: benrebahf@yahoo.fr waste and wastewater. Solid waste which represents $20-60 \%$ of the initial raw material contains various kinds of residues (whole waste fish, fish head, viscera, skin, bones, blood, frame liver, gonads, guts, some muscle tissue, etc.) (Awarenet 2004). In some countries, these discards are not utilized, but incinerated or dumped at sea causing environmental problems (Bozzano and Sarda 2002). Recently, environmental regulations are becoming stricter, requiring new disposal methods based on the fact that fish wastes (solid waste and wastewater) may considered as an important source of protein, lipids and minerals with high biological value (Toppe et al. 2007; Kacem et al. 2011).

To avoid wasting by-products, various conventional disposal methods have been applied including ensilation and fermentation for the production of high-protein meals for animal feeds (Faid et al. 1997; Hassan and Heath 1986) as well as composting (Liao et al. 1997). Recent advances in industrial biotechnology process are exploited for an economic utilization of wastes in producing higher added value products. For example, fish oil with higher level of polyunsaturated fatty acids beneficial for human health (Kim et al. 2006; Zampolli et al. 2006; Chen et al. 2006) was produced and integrated into food products and beverages (Rubio-Rodriguez et al. 2010). Moreover, fish skin or cartilage from some species could be excellent raw materials for producing gelatin or chondroitin sulphate useful in food, cosmetic and pharmaceutical sectors (Blanco et al. 2006; Karim and Bhat 2009). By-products can be also hydrolysed by applying various treatments (heat, enzymatic and chemical treatments) and the hydrolysate quality can be also improved by fermentation (Yamamoto et al. 2005; Yano et al. 2008; Xu et al. 2008). Generally, the obtained hydrolysates may have biological and functional properties of interest in various sectors

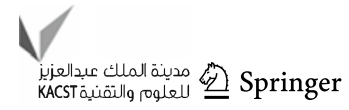


(human nutrition, cosmetology, aquaculture, microbiology, etc.) (Ben Rebah et al. 2008; Liaset et al. 2000; Martone et al. 2005). For example, proteolytic hydrolyses were reported to produce peptides with interesting biological activities (anti-hypertensers, immuno-modulators, antioxidants, anticoagulants, etc.) useful in the treatment of several diseases (osteoporosis, arthritis, diabetes, obesity, etc.) (Kim and Mendis 2006).

Interestingly, fish by-products provide an excellent source for microbial growth, which can be exploited in producing various metabolites (lysine, enzymes, etc.) (Coello et al. 2000; Vazquez et al. 2006, 2008). A large number of microorganisms including bacteria, yeast and fungi produce different groups of enzymes (protease, lipase, etc.) having high biotechnological interest (food processing, detergent, textile, pharmaceutical products, medical therapy, etc.) (Underkofler et al. 1958). Microbial synthesis of enzymes has been reported to be influenced by various factors such as carbon sources, nitrogen sources, and operating parameters (temperature, $\mathrm{pH}$, etc.) (Frost and Moss 1987; Gupta et al. 2004; Jacob and Prema 2006; Palaniyappan et al. 2009). Generally, agro-industrial residues mainly composed of complex polysaccharides are considered the best substrates for microbial growth and enzyme production (Pandey et al. 1999). The economies of this process are governed mostly by the cost and availability of a suitable carbon and nitrogen sources. Therefore, the investigation of low cost substrates easily available such as fish processing wastes became a necessity opening new avenues for their effective production and utilization. In this review, we will present the potential of different fish processing by-products tested as growth substrates for microbial enzyme production.

\section{Proteases}

Proteases are one of the most important groups of industrial enzymes, representing more than $65 \%$ of the of global industrial enzyme market (Banik and Prakash 2004). Various microorganisms have been used to produce these enzymes (Penicillium sp. Serratia marcescens, Streptomyces sp., Rhizopus oryzae, Pseudomonas, Bacillus sp., Vibrio, etc.) (Banerjee et al. 1993; De Azeredo et al. 2004; Joo and Chang 2005; Vazquez et al. 2006).

Because of their vast diversity and their specificity of action, proteases have a large variety of biotechnological applications (Kumar and Takagi 1999; Gupta et al. 2002). Their use involves different industrial sectors, such as the detergent industries (Banik and Prakash 2004), bioremediation processes (Roberts et al. 2007), leather industry (Taylor et al. 1987), bioprocessing of used X-ray films for silver recovery (Fujiwara and Yamamoto 1987) pharmaceutical industries and protein hydrolysate production (Banik and Prakash 2004). Recently, the application of protease in producing bioactive peptide has received great attention as a viable alternative to chemical approach (Suetsuna 2000; Ma et al. 2007).

Numerous investigators have looked for ways of producing microbial proteases using inexpensive media. Interestingly, it was demonstrated that fish processing wastes (fish meat wastes, chitinous material from cephalopods and wastewater) offer good potential for this purpose (Triki-Ellouz et al. 2003; Vazquez et al. 2006; Wang and Yeh 2006; Haddar et al. 2010).

Fish processing by-products including heads and viscera were utilized for preparing microbial growth media. In some cases, fish wastes were cooked, pressed, minced and then dried $\left(80^{\circ} \mathrm{C}\right.$ for $\left.24-48 \mathrm{~h}\right)$ in order to obtain fish powder. In other cases, wastes were boiled in water and supernatants were recuperated. Moreover, protein hydrolysates obtained by acid, alkali, or enzymatic treatments of raw or defatted by-products were also used as a nitrogen source for protease production (Coello et al. 2000; TrikiEllouz et al. 2003). Generally, fish powder or supernatants were added to the microbial basal medium (Table 1). For example, Pseudomonas aeruginosa MN7 and Bacillus subtilis were cultivated in media containing combined heads and viscera powder allowing an acceptable level of protease production (Ellouz et al. 2001; Triki-Ellouz et al. 2003). Similarly, marine peptones obtained from fish viscera of various marine species (rainbow trout "Oncorhynchus mykiss", swordfish "Xiphias gladius", squid "Loligo vulgaris" and yellowfin tuna "Thunnus albacares") allowed higher levels of protease activity for two vibrio species (Vibrio anguillarum and Vibrio splendidus) while compared to basal medium containing commercial peptones (Vazquez et al. 2006). According to Esakkiraj et al. (2009), a defatted tuna waste allowed higher level of protease activity by Bacillus cereus $(134.57 \mathrm{U} / \mathrm{ml})$ while compared to acid and alkali hydrolysates (60.37 and $65.96 \mathrm{U} / \mathrm{ml}$, respectively) and to commercial peptone $(124.90 \mathrm{U} / \mathrm{ml})$. The enhancement of protease production in the defatted fish-based medium may be attributed to the lipid-free nature of product, which could support the protease synthesis by the microbial species than other nitrogen source preparations. A similar observation was notified for lipase production by Rhizopus oryzae (Ghorbel et al. 2005). More recently, a significant improvement of the alkaline protease production by Bacillus mojavensis A21 was obtained using Sardinella peptone (Haddar et al. 2010). However, is very important to note that optimal protease production is controlled by several growth conditions such as the medium composition (carbon and nitrogen sources, mineral salts, etc.), agitation, culture temperature and initial medium, $\mathrm{pH}$, etc. 
Table 1 Protease production by various microbial strains grown in fish processing waste based media

\begin{tabular}{|c|c|c|c|c|}
\hline Fish raw materials & Preparation of the growth media ${ }^{a}$ & $\begin{array}{l}\text { Microbial } \\
\text { strains }\end{array}$ & $\begin{array}{l}\text { Activity } \\
(\mathrm{U} / \mathrm{ml})\end{array}$ & References \\
\hline Heads and viscera of Sardinella & $\begin{array}{l}\text { Raw materials cooked, pressed, minced } \\
\text { and dried }\left(80^{\circ} \mathrm{C}, 24-48 \mathrm{~h}\right)\end{array}$ & $\begin{array}{l}\text { Pseudomonas } \\
\text { aeruginosa } \mathrm{MN} 7\end{array}$ & 7,800 & Triki-Ellouz et al. (2003) \\
\hline Heads and viscera of Sardinella & $\begin{array}{l}\text { Raw materials cooked, pressed, minced } \\
\text { and dried }\left(80^{\circ} \mathrm{C}, 24-48 \mathrm{~h}\right)\end{array}$ & Bacillus subtilis & 720 & Ellouz et al. (2001) \\
\hline $\begin{array}{l}\text { Viscera from rainbow trout, } \\
\text { swordfish, squid and } \\
\text { yellowfin tuna }\end{array}$ & $\begin{array}{l}\text { Raw materials ground with water and } \\
\text { supernatants recovered by centrifugation } \\
\text { and used to prepare the peptone }\end{array}$ & Vibrio anguillarum & $35-68$ & Vazquez et al. (2006) \\
\hline $\begin{array}{l}\text { Viscera from rainbow trout, } \\
\text { swordfish, squid and } \\
\text { yellowfin tuna }\end{array}$ & $\begin{array}{l}\text { Raw materials were ground with water } \\
\text { and supernatants recovered by } \\
\text { centrifugation and used } \\
\text { to prepare the peptone }\end{array}$ & Vibrio splendidus & $9-30$ & Vazquez et al. (2006) \\
\hline Raw tuna waste & $\begin{array}{l}\text { Raw materials cooked, bones removed, } \\
\text { pressed to remove water and fat, } \\
\text { pressed, minced and dried } \\
\left(80^{\circ} \mathrm{C}, 24-48 \mathrm{~h}\right)\end{array}$ & Bacillus cereus & 74.77 & Esakkiraj et al. (2009) \\
\hline Defatted tuna waste & Extraction with chloroform/methanol & Bacillus cereus & 134.57 & Esakkiraj et al. (2009) \\
\hline Acid-hydrolyzed tuna waste & Method described by Gao et al. (2006) & Bacillus cereus & 60.37 & Esakkiraj et al. (2009) \\
\hline Alkali-hydrolyzed tuna waste & Method described by Batista (1999) & Bacillus cereus & 65.96 & Esakkiraj et al. (2009) \\
\hline
\end{tabular}

${ }^{a}$ The obtained fish powder was added to the basal medium

Several microbial strains grown in basal medium supplemented with different chitinous material preparations [shrimp shell powder (SSP), squid pen powder (SPP), chitin flake of shrimp shell (CFSS), chitin flake of crab shell (CFCS), shrimp and crab shell powder (SCSP)] (Table 2) were tested for protease activity. Generally, chitinous materials collected from marine food processing industry were treated (dried, milled, and sieved to powder with diameters of $<0.053 \mathrm{~mm}$ ) and added to the basal medium at different proportions as reported by Wang et al. (2002a). According to Table 2, protease activity was affected by the nature of the strain and the used carbon/ nitrogen sources. For example, for both Bacillus subtilis TKU007 and Bacillus sp. TKU004, SSP was more suitable for protease production (Wang and Yeh 2006) than the other carbon/nitrogen sources. However, for the production of protease by $L$. paracase $i$ subsp. paracasei TKU010, SPP $(0.12 \mathrm{U} / \mathrm{ml})$ was more suitable than SSP $(0.08 \mathrm{U} / \mathrm{ml})$ (Wang et al. 2008a). Also, in the case of Serratia ureilytica TKU013, SPP $(0.200 \mathrm{U} / \mathrm{ml})$ was more suitable than SSP $(0.190 \mathrm{U} / \mathrm{ml})$ (Wang et al. 2009a). According to Wang et al. (2008b), higher protease activity might be controlled by the ratio of protein and chitin. In the findings of Wang et al. (2008b), the ratio of protein and chitin (48:38) in SSP is much closer than that of SPP (61:38) allowing a protease activity by Chryseobacterium sp. TKU014 of 0.010 and $0.007 \mathrm{U} / \mathrm{ml}$ with SSP and SPP, respectively. In addition to that, mineral salts may have a suppressed role on the protease productivity as reported for $L$. paracase $i$ subsp. paracasei TKU010 and TKU012 (Wang et al. 2008a).
In order to enhance the protease production, shrimp and crab shell powder were treated using chemical reagents $(\mathrm{HCl}, \mathrm{NaOH}$ and $\mathrm{HCl} / \mathrm{NaOH}$ (Oh et al. 2000) and used for microbial growth. The chemical treatments and the rate of the preparation added to the microbial basal medium affect considerably the time of growth and the protease activity as reported by Liang et al. (2006) for Monascus purpureus CCRC31499. Interestingly, protease produced under optimal culture conditions can be exploited in the deproteinization of shrimp and crab shell wastes. For example, it was demonstrated that protease of $P$. aeruginosa K-187 allowed higher protein removal from crustacean wastes. The removal rates were about $72 \%$ for shrimp and crab shell powder, $78 \%$ for natural shrimp shell and $45 \%$ for acid-treated shrimp and crab shell powder (Oh et al. 2000).

Wastewater from fish processing industry supplemented with cuttlefish by-products powder was also tested as growth media for microbial growth and protease production by five bacterial species (Bacillus licheniformis, Bacillus subtilis, Pseudomonas aeruginosa, Bacillus cereus BG1, and Vibrio parahaemolyticus). According to Souissi et al. (2008), all the tested strains can obtain their carbon and nitrogen source requirements directly from proteins of the cuttlefish by-products and, interestingly, the addition of the fishery wastewater improved the protease activity. For example, the protease activity of Bacillus cereus BG1, increased from $467 \mathrm{U} / \mathrm{ml}$ to reach $2771 \mathrm{U} / \mathrm{ml}$ while adding fishery wastewater to the cuttlefish by-product-based medium (Table 3 ). The positive effect on protease activity 
Table 2 Protease production by various microbial strains grown in chitinous material based media

\begin{tabular}{|c|c|c|c|}
\hline $\begin{array}{l}\text { Chitinous materials (rate added to } \\
\text { the basal medium in } \% \mathrm{w} / \mathrm{v} \text { ) }\end{array}$ & Microbial strains & $\begin{array}{l}\text { Protease } \\
\text { activity (U/ml) }\end{array}$ & References \\
\hline \multicolumn{4}{|l|}{ Shrimp shell powder $(\mathrm{SSP})^{\mathrm{a}}$} \\
\hline 1 & Chryseobacterium sp. TKU014 & 0.010 & Wang et al. (2008b) \\
\hline 1.5 & Bacillus subtilis TKU007 & 0.350 & Wang and Yeh (2006) \\
\hline 1 & Bacillus subtilis TKU007 & 0.350 & Wang and Yeh (2006) \\
\hline 1 & Bacillus sp. TKU004 & 0.090 & Wang et al. (2006a) \\
\hline 1 & Lactobacillus paracasei subsp paracasei TKU010 & 0.080 & Wang et al. (2008a) \\
\hline 1 & Lactobacillus paracasei subsp paracasei TKU012 & 0.130 & Wang et al. (2008c) \\
\hline 1.5 & Serratia ureilytica TKU013 & 0.190 & Wang et al. (2009a) \\
\hline 2 & Bacillus cereus TKU006 & 2.070 & Wang et al. (2009b) \\
\hline 1 & Serratia sp. TKU016 & 0.160 & Wang et al. (2010) \\
\hline \multicolumn{4}{|l|}{ Squid pen powder $(\mathrm{SPP})^{\mathrm{a}}$} \\
\hline 2 & Bacillus sp. TKU004. & 0.065 & Wang et al. (2006a) \\
\hline 1 & Chryseobacterium sp. TKU014 & 0.007 & Wang et al. (2008b) \\
\hline 2 & Bacillus subtilis TKU007 & 0.220 & Wang and Yeh $(2006)$ \\
\hline 1 & Bacillus subtilis TKU007 & 0.220 & Wang and Yeh (2006) \\
\hline 1 & Bacillus sp. TKU004 & 0.060 & Wang et al. (2006a) \\
\hline 1 & Lactobacillus paracasei subsp paracasei TKU010 & 0.120 & Wang et al. (2008a) \\
\hline 1 & Lactobacillus paracasei subsp paracasei TKU012 & 0.140 & Wang et al. (2008c) \\
\hline 1.5 & Serratia ureilytica TKU013 & 0.200 & Wang et al. (2009a) \\
\hline 1 & Serratia sp. TKU016 & 0.090 & Wang et al. (2010) \\
\hline \multicolumn{4}{|l|}{ Chitin flake of shrimp shell (CFSS) } \\
\hline 2 & Bacillus subtilis TKU007 & $<0.010$ & Wang and Yeh $(2006)$ \\
\hline 1 & Bacillus subtilis TKU007 & $<0.010$ & Wang and Yeh (2006) \\
\hline 1 & Bacillus sp. TKU004 & $<0.010$ & Wang et al. (2006a) \\
\hline 1 & Lactobacillus paracasei subsp paracasei TKU010 & $<0.010$ & Wang et al. (2008a) \\
\hline 1 & Lactobacillus paracasei subsp paracasei TKU012 & $<0.010$ & Wang et al. (2008c) \\
\hline \multicolumn{4}{|l|}{ Chitin flake of crab shell (CFCS) } \\
\hline 2 & Bacillus subtilis TKU007 & $<0.010$ & Wang and Yeh $(2006)$ \\
\hline 1 & Bacillus subtilis TKU007 & $<0.010$ & Wang and Yeh (2006) \\
\hline 1 & Bacillus sp. TKU004 & $<0.010$ & Wang et al. (2006a) \\
\hline 1 & Lactobacillus paracasei subsp paracasei TKU010 & $<0.010$ & Wang et al. (2008a) \\
\hline 1 & Lactobacillus paracasei subsp paracasei TKU012 & $<0.010$ & Wang et al. (2008c) \\
\hline \multicolumn{4}{|l|}{ Shrimp and crab shell powder (SCSP) } \\
\hline 1 & Bacillus subtilis TKU007 & nd & Wang and Yeh $(2006)$ \\
\hline 1 & Bacillus sp. TKU004 & 0.060 & Wang et al. (2006a) \\
\hline 1 & Lactobacillus paracasei subsp paracasei TKU012 & 0.090 & Wang et al. (2008c) \\
\hline 1 & Lactobacillus paracasei subsp paracasei TKU010 & 0.040 & Wang et al. (2008a) \\
\hline
\end{tabular}

nd not detectable

${ }^{\text {a }}$ Dried materials of SPP, SSP were prepared as described earlier (Wang et al. 2002a)

may be explained by the presence of very specific growth factors and amino-acids in the fishery wastewater.

The diversified utilization of fish processing wastes as potential media for microbial proteases production is expected to deliver an attractive and promising strategy for enzyme large-scale production. In commercial practice, the optimization of medium composition is done to maintain a balance between the various microbial growth nutrients. However, no defined medium has been established for the best production of proteases from different microbial sources. Generally, each microbial strain has its own special conditions for maximum enzyme production. Therefore, experiments should be conducted to elucidate the behaviour of each strain with each fish waste to identify 
Table 3 Proteases produced by some microbial strains cultivated in fishery waste based media (Souissi et al. 2008)

\begin{tabular}{|c|c|c|c|c|}
\hline Strains & Type of protease & Growth media & Protease activity $(\mathrm{U} / \mathrm{ml})$ & Time of growth (h) \\
\hline \multirow{2}{*}{ Bacillus cereus BG1 } & \multirow[t]{2}{*}{ Metalloprotease } & $\mathrm{M}^{\mathrm{a}}$ & 487 & 48 \\
\hline & & $\mathrm{M}+\mathrm{FWW}^{\mathrm{b}}$ & $756-2,771$ & 48 \\
\hline \multirow[t]{2}{*}{ Bacillus subtilis } & \multirow[t]{2}{*}{ Serine protease } & $\mathrm{CF}^{\mathrm{c}}$ & 178 & 16 \\
\hline & & $\mathrm{CF}+\mathrm{FWW}^{\mathrm{d}}$ & $0-392$ & 16 \\
\hline \multirow[t]{2}{*}{ Bacillus licheniformis } & \multirow[t]{2}{*}{ Serine protease } & $\mathrm{CF}$ & 407 & 24 \\
\hline & & $\mathrm{CF}+\mathrm{FWW}$ & $138-821$ & 24 \\
\hline \multirow[t]{2}{*}{ Pseudomonas aeruginosa } & \multirow[t]{2}{*}{ Metalloprotease } & $\mathrm{CF}$ & 1,680 & 24 \\
\hline & & $\mathrm{CF}+\mathrm{FWW}$ & $160-1,694$ & 24 \\
\hline \multirow[t]{2}{*}{ Vibrio parahaemolyticus } & \multirow[t]{2}{*}{ Serine protease } & $\mathrm{CF}$ & 1,607 & 24 \\
\hline & & $\mathrm{CF}+\mathrm{FWW}$ & $196-2,487$ & 24 \\
\hline
\end{tabular}

${ }^{\mathrm{a}} \mathrm{M}: 10 \mathrm{~g} / \mathrm{l}$ of maltose and $10 \mathrm{~g} / \mathrm{l}$ of cuttlefish by-products powder in artificial sea water (Krieg and Holt 1984)

${ }^{\mathrm{b}} \mathrm{M}+$ FWW: M mixed with FWW (fishery wastewater) at different concentrations

${ }^{\mathrm{c}} \mathrm{CF}$ : cuttlefish by-product medium ( $\mathrm{g} / \mathrm{l}$ of cuttlefish by-products powder in distilled water; Cuttlefish by-products powder was prepared from guts and stomachs (rinsed, heated, pressed, then, minced and dried at $80{ }^{\circ} \mathrm{C}$ for $24-48 \mathrm{~h}$ as reported by Souissi et al. 2008

${ }^{\mathrm{d}} \mathrm{CF}+\mathrm{FWW}$ medium: CF prepared in crude and diluted FWW

inducers present in the fish waste. These researches would provide the incentive for commercial developments leading to large-scale and cost-effective production of proteases.

\section{Lipases}

Lipases are a class of enzymes which catalyse the hydrolysis of long chain triglycerides and are of considerable commercial interest in various industrial applications (detergent, food, flavour industry, biocatalytic resolution of pharmaceuticals, esters and amino acid derivatives, fine chemicals, agrochemicals, use as biosensor, bioremediation, cosmetics, perfumery, etc.) (Hasan et al. 2006). With the rapid development of enzyme technology, lipases are currently receiving much attention involving various selected microorganisms especially from fungi, bacteria, and yeasts (Sharma et al. 2001).

Numerous investigators have looked for ways of producing microbial lipases using low cost media. A variety of fish processing by-products contain growth factors offering good potential as culture media, as shown by the high level of lipase activity produced by some microbial strains (Table 4). As reported in Table 4, various pre-treatment processes (heat treatment, chemical and enzymatic treatment, etc.) were applied on fish wastes before being used as growth media (Ben Rebah et al. 2008; Esakkiraj et al. 2010a). For example, lipase activity of Staphylococcus xylosus was evaluated in supernatants generated from boiled fish wastes (tuna, sardine, cuttlefish, and shrimp by-products) supplemented or not with the basal growth medium (containing $17 \mathrm{~g} / \mathrm{l}$ casein peptone, $5 \mathrm{~g} / \mathrm{l}$ yeast extract and $2.5 \mathrm{~g} / \mathrm{l}$ glucose). Depending on the waste origin and the proportion of the added basal medium, lipase activity varied much among the tested samples and supernatants generated from shrimp and cuttlefish by-products exhibited the highest lipase activity (28 U/ml) (Ben Rebah et al. 2008). Similar experiments were reported while growing Staphylococcus epidermidis CMST Pi 2 (isolated from the intestine of shrimp Penaeus indicus) in a medium containing raw and treated (defatted, alkali and acid hydrolysates) tuna byproducts (Esakkiraj et al. 2010a).

A major concern associated with the use of fish wastes for microbial lipase production is the presence of lipids. A defatted fish meat preparation allowed a maximum lipase production (the optimum activity reached $14.20 \mathrm{U} / \mathrm{ml}$ while increasing the concentration of defatted fish meat) by Staphylococcus epidermidis CMST Pi 2 (Esakkiraj et al. 2010a). This observation confirmed the inhibitory effect of lipids on microorganism growth, as it was found when growing marine bacteria in fish peptone-based media (Vazquez et al. 2004) and Staphylococcus xylosus in tuna and sardine by-product-based media (Ben Rebah et al. 2008). In addition to that, regarding the effect of triglycerides on lipase production, cod liver oil showed as a suitable triglyceride to increase lipase production by Staphylococcus epidermidis CMST Pi 1 (Esakkiraj et al. 2010b).

Generally, microbial lipase production is highly influenced by medium components like nitrogen sources, carbon sources such as fatty acids, triglycerides and carbohydrates which can stimulate or repress lipase production. However, an adequate balance of nutrients and specific factors would ensure higher lipase activity (Ben Rebah et al. 2008; Ghorbel et al. 2005).

It appears, therefore, that there is a definite need for optimizing the microbial lipase production taking into consideration various factors especially the fish waste composition and microbial strain nutrient requirements. As 
Table 4 Production of lipase by different microbial species grown in fish processing by-products

\begin{tabular}{|c|c|c|c|c|}
\hline Fish raw materials & Preparation of the growth media & Microbial strains & $\begin{array}{l}\text { Lipase } \\
\text { activity } \\
(\mathrm{U} / \mathrm{ml})\end{array}$ & References \\
\hline $\begin{array}{r}\text { Defatted tuna } \\
\text { by-products }\end{array}$ & Extraction with chloroform/methanol ${ }^{\mathrm{a}}$ & $\begin{array}{l}\text { Staphylococcus epidermidis } \\
\text { CMST Pi } 2\end{array}$ & 12.63 & $\begin{array}{l}\text { Esakkiraj et al. } \\
\text { (2010a) }\end{array}$ \\
\hline $\begin{array}{r}\text { Defatted tuna } \\
\text { by-products }\end{array}$ & Extraction with chloroform/methanol ${ }^{\mathrm{a}}$ & $\begin{array}{l}\text { Staphylococcus epidermidis } \\
\text { CMST Pi } 2\end{array}$ & 14.20 & $\begin{array}{l}\text { Esakkiraj et al. } \\
\text { (2010a) }\end{array}$ \\
\hline Tuna by-products & $\begin{array}{l}\text { Raw materials were cooked, bones were removed, } \\
\text { pressed to remove water and fat, pressed, minced and } \\
\text { dried }\left(80^{\circ} \mathrm{C}, 24-48 \mathrm{~h}\right)^{\mathrm{a}}\end{array}$ & $\begin{array}{l}\text { Staphylococcus epidermidis } \\
\text { CMST Pi } 2\end{array}$ & 8.17 & $\begin{array}{l}\text { Esakkiraj et al. } \\
(2010 \mathrm{a})\end{array}$ \\
\hline $\begin{array}{l}\text { Acid-hydrolyzed } \\
\text { tuna waste }\end{array}$ & Method described by Gao et al. $(2006)^{\mathrm{a}}$ & $\begin{array}{l}\text { Staphylococcus epidermidis } \\
\text { CMST Pi } 2\end{array}$ & 8.03 & $\begin{array}{l}\text { Esakkiraj et al. } \\
\text { (2010a) }\end{array}$ \\
\hline $\begin{array}{l}\text { Alkali-hydrolyzed } \\
\text { tuna waste }\end{array}$ & Method described by Batista (1999) ${ }^{a}$ & $\begin{array}{l}\text { Staphylococcus epidermidis } \\
\text { CMST Pi } 2\end{array}$ & 8.13 & $\begin{array}{l}\text { Esakkiraj et al. } \\
(2010 \mathrm{a})\end{array}$ \\
\hline $\begin{array}{l}\text { Shrimp } \\
\text { by-products }\end{array}$ & $\begin{array}{l}\text { Raw materials were boiled }\left(100{ }^{\circ} \mathrm{C} \text { for } 20 \mathrm{~min}\right) \text { in water } \\
\text { and supernatants were recuperated by centrifugation }{ }^{\mathrm{b}}\end{array}$ & Staphylococcus xylosus & $19-28$ & $\begin{array}{l}\text { Ben Rebah } \\
\text { et al. (2008) }\end{array}$ \\
\hline $\begin{array}{l}\text { Cuttlefish } \\
\text { by-products }\end{array}$ & $\begin{array}{l}\text { Raw materials were boiled }\left(100{ }^{\circ} \mathrm{C} \text { for } 20 \mathrm{~min}\right) \text { in water } \\
\text { and supernatants were recuperated by centrifugation }{ }^{\text {b }}\end{array}$ & Staphylococcus xylosus & $5-9.50$ & $\begin{array}{l}\text { Ben Rebah } \\
\text { et al. (2008) }\end{array}$ \\
\hline Tuna by-products & $\begin{array}{l}\text { Raw materials were boiled }\left(100{ }^{\circ} \mathrm{C} \text { for } 20 \mathrm{~min}\right) \text { in water } \\
\text { and supernatants were recuperated by centrifugation }\end{array}$ & Staphylococcus xylosus & $0-4$ & $\begin{array}{l}\text { Ben Rebah } \\
\text { et al. (2008) }\end{array}$ \\
\hline $\begin{array}{l}\text { Sardine } \\
\text { by-products }\end{array}$ & $\begin{array}{l}\text { Raw materials were boiled }\left(100{ }^{\circ} \mathrm{C} \text { for } 20 \mathrm{~min}\right) \text { in water } \\
\text { and supernatants were recuperated by centrifugation }{ }^{\text {b }}\end{array}$ & Staphylococcus xylosus & $0-3$ & $\begin{array}{l}\text { Ben Rebah } \\
\text { et al. (2008) }\end{array}$ \\
\hline Cod liver oil & $1 \%$ of fish oil added to the basal medium & $\begin{array}{l}\text { Staphylococcus epidermidis } \\
\text { CMST Pi } 1\end{array}$ & 14.8 & $\begin{array}{l}\text { Esakkiraj et al. } \\
(2010 \mathrm{~b})\end{array}$ \\
\hline
\end{tabular}

a The obtained fish powder was added to the basal medium at different proportions

b The supernatant was used as a nutrient source for lipase production

pointed for proteases, the reported studies offer further exciting possibilities for the industrial use of the fish processing wastes.

\section{Chitinolytic enzymes}

Chitinolytic enzymes are enzymes that degrade chitin and they are produced by various organisms such as viruses, bacteria, fungi, insects, higher plants and animals (Park et al. 1997). For example, these enzymes have been reported in several microorganisms such as $S$. marcescens (Suzuki et al. 2002), Bacillus licheniformis X-74 (Takayanagi et al. 1991), Aeromonas sp. No. 10S-24 (Ueda et al. 1995), Streptomyces sp. J. 13-3 (Okazaki et al. 1995), Pseudomonas aeruginosa K-187 (Wang and Chang 1997) and Streptomyces griseus HUT 6037 (Itoh et al. 2002). Recently, many novel chitinase/chitosanase producing microorganisms have been screened out from Taiwan soil (Wang et al. 2011).

Chitinolytic enzymes have various potential applications such as preparation of chitooligosaccharides and $\mathrm{N}$-acetyl D-glucosamine which are known to have various biological activities (antimicrobial, antifungal, immunoenhancers, antitumor, etc.) (Tsai et al. 2000; Shen et al. 2009) with high interest in the pharmaceutical sector (Wen et al. 2002). Moreover, chitinases can be used for the control of pathogenic fungi in agriculture (Dahiya et al. 2005) and the degradation of crustacean chitinous waste in sea food industry. These enzymes are also useful for the preparation of single-cell protein, the isolation of protoplasts from fungi and yeast, etc. (Dahiya et al. 2006).

Microbial chitinase has been produced by liquid fermentation processes (batch, continuous and fed-batch fermentation) and is commercially available at a high cost (Dahiya et al. 2006). Generally, the production is controlled by physical factors (aeration, $\mathrm{pH}$, and incubation temperature) and by the growth media components (Miyashita et al. 1991).

In order to increase the supply of active chitinase, it is necessary to reduce the production cost by using wastes for microbial growth. In this perspective, various chitinous materials from marine sources [shrimp shell powder (SSP), squid pen powder (SPP), shrimp and crab shell powder (SCSP)] have been utilized for chitinolytic enzyme production (Table 5) as alternative to waste disposal.

Interestingly, using shellfish chitin-containing wastes as the sole carbon/nitrogen source for chitinase/protease-producing strains can be exploited as potential biocontrol agents (Wang et al. 2006b). For example, SCSP of marine 
Table 5 Microbial production of chitinolytic enzymes using chitinous materials

\begin{tabular}{|c|c|c|c|c|}
\hline $\begin{array}{l}\text { Chitinous materials (rate added to } \\
\text { the basal medium in } \% \mathrm{w} / \mathrm{v} \text { ) }\end{array}$ & Microbial strains & $\begin{array}{l}\text { Enzyme } \\
\text { type }\end{array}$ & $\begin{array}{l}\text { Enzyme activity } \\
(\mathrm{U} / \mathrm{mL})\end{array}$ & References \\
\hline \multicolumn{5}{|l|}{ Shrimp shell powder (SSP) } \\
\hline 0.5 & Pseudomonas sp. TKU015 & Chitosanase & 0.026 & Wang et al. (2008e) \\
\hline 0.5 & Pseudomonas sp. TKU015 & Chitinase & 0.011 & Wang et al. (2008e) \\
\hline 1 & Bacillus cereus TKU018 & Chitosanase & 0.020 & Wang et al. (2009d) \\
\hline 1.5 & Bacillus subtilis TKU007 & Chitosanase & 0.030 & Wang and Yeh (2008) \\
\hline 2 & Bacillus cereus TKU006 & Chitinase & 0.089 & Wang et al. (2009b) \\
\hline 1.5 & Serratia ureilytica TKU013 & Chitinase & 0.032 & Wang et al. 2009a \\
\hline 0.5 & Serratia sp. TKU020 & Chitinase & 0.180 & Wang et al. (2009c) \\
\hline 0.5 & Serratia sp. TKU020 & Chitosanase & 0.400 & Wang et al. (2009c) \\
\hline 1 & Serratia sp. TKU016 & Chitosanase & 0.022 & Wang et al. (2010) \\
\hline \multicolumn{5}{|l|}{ Squid pen powder (SPP) } \\
\hline 3 & Bacillus sp. TKU004 & Chitosanase & $0.14-0.16$ & Wang et al. (2009e) \\
\hline 1.5 & Serratia ureilytica TKU013 & Chitinase & 0.037 & Wang et al. (2009a) \\
\hline 2 & Serratia marcescens TKU011 & Chitosanase & 0.030 & Wang et al. (2008d) \\
\hline 0.5 & Serratia sp. TKU020 & Chitosanase & 0.420 & Wang et al. (2009c) \\
\hline 1 & Serratia sp. TKU016 & Chitosanase & 0.008 & Wang et al. (2010) \\
\hline \multicolumn{5}{|l|}{ Shrimp and crab shell powder (SCSP) } \\
\hline 3 & Pseudomonas aeruginosa K-187 & Chitinase & 0.650 & Wang and Chang (1997) \\
\hline 2 & Bacillus amyloliquefaciens V656 & Chitinase & 0.017 & Wang et al. (2002a) \\
\hline 2 & Bacillus cereus YQ308 & Chitinase & 1.400 & Chang et al. (2003) \\
\hline 3 & Bacillus subtilis $\mathrm{W}-118$ & Chitinase & 4.200 & Wang et al. (2006b) \\
\hline 1 & Monascus purpureus CCRC31499 & Chitinase & 0.080 & Wang et al. (2002b) \\
\hline
\end{tabular}

Dried materials of SPP SSP was prepared as described earlier (Wang et al. 2002a)

wastes induce the production of antimicrobial chitinases by P. aeruginosa K-187 (Wang and Chang 1997), B. amyloliquefaciens V656 (Wang et al. 2002a), B. cereus YQ308 (Chang et al. 2003), B. subtilis W-118 (Wang et al. 2006b) and M. purpureus CCRC31499 (Wang et al. 2002b). Moreover, $P$. aeruginosa $\mathrm{K}-187$ isolated from the soil using SCSP as sole $\mathrm{C} / \mathrm{N}$ source showed two kinds of bifunctional chitinases/lysozymes having antibacterial and cell lysis activities against many bacterial species (Wang et al. 1995; Wang and Chang 1997).

Silage obtained by lactic acid fermentation of shrimp head wastes containing chitin, proteins lipids and minerals was also used as substrate and inducer of $\beta$ - $N$-acetylhexosaminidases of Verticillium lecanii in submerged fermentations (SF) and solid-state fermentations (SSF) (Shirai et al. 2001). The addition of sucrose or sugar cane pith bagasse reduces the growth time of $V$. lecanii (Matsumoto et al. 2001, 2004). Interestingly, a mixture of shrimp waste silage and sugar cane pith bagasse in SSF improved significantly the enzyme yield (Matsumoto et al. 2004). Chitinous materials from marine sources can be considered as good inducers for microbial chitinase production.

\section{Ligninolytic enzymes}

Lignin is the most abundant natural aromatic polymer on earth and degradation of this recalcitrant aromatic polymer is caused by ligninolytic system from natural process in plants, animals, fungi and bacteria (Kirk and Farrell 1987). The ligninolytic system is an extracellular enzymatic complex including peroxidases, laccases and oxidases (Ruiz-Duenas and Martinez 2009). Ligninolytic enzymes have capacities to remove xenobiotic substances (such as hydrocarbons, phenols, perchloroethylene, azo dyes, carbon tetrachloride aromatics, pesticides, lignin, humic substances, etc.) which are introduced into the environment by numerous industrial activities. The presence of these xenobiotics in the environment can pose dangerous and unstable situations, because of their possible harmful effects on many organisms (Danzo 1997; Birnbaum 1994). Therefore, ligninolytic enzymes have potential applications in various sectors such as chemical, fuel, food, agricultural, paper, textile, cosmetic industrial sectors and in bioremediation purposes (Rodríguez and Toca 2006).

Generally, ligninolytic enzymes exhibit differential characteristics depending on various factors such as 
Table 6 Maximum enzyme activity during growth (expressed in units/gram dry substrate) by solid-state cultures of Phanerochaete chrysosporium BKM-F-1767 in fishery residues compared to apple waste with and without inducer (Gassara et al. 2010)

\begin{tabular}{llll}
\hline Enzymes & $\begin{array}{l}\text { Without } \\
\text { inducer }\end{array}$ & $\begin{array}{l}\text { With veratryl } \\
\text { alcohol }\end{array}$ & $\begin{array}{l}\text { With copper } \\
\text { sulphate }\end{array}$ \\
\hline $\begin{array}{l}\text { Fishery residues } \\
\text { Manganese peroxidase }\end{array}$ & 47.4 & 17 & 17.4 \\
$\begin{array}{l}\text { Lignin peroxidase } \\
\text { Laccase }\end{array}$ & nd & nd & nd \\
Apple waste & nd & nd & 94.4 \\
Manganese peroxidase & 243.7 & 631.25 & 213.5 \\
Lignin peroxidase & nd & nd & nd \\
Laccase & nd & 141.4 & 719.9 \\
\hline
\end{tabular}

$n d$ not detectable

species, strains and culture conditions (Kirk and Farrell 1987). However, their production is very expensive and controlled by the raw material used for growth (Hacking 1987). In this perspective, various wastes such as apple pomace (Vendruscolo et al. 2008; Gassara et al. 2010), brewery by-product (Bartolome et al. 2003; Gassara et al. 2010), municipal and industrial sludge (Gassara et al. 2010) were used to produce ligninolytic enzymes (pectinase, lignin peroxidase, manganese peroxidase, cellulase and xylanase). The only study reporting the production of ligninolytic enzymes using fishery waste was that of Gassara et al. (2010). In this study, the production of lignin peroxidase, manganese peroxidase and laccase by Phanerochaete chrysosporium BKM-F-1767 was investigated in fishery residues (from SAUMMOM Inc., Montreal, Canada) by solid-state cultures (Table 6). Compared to apple wastes, the poor results of $P$. chrysosporium in fishery residues may be related to the unavailability of nutrients and the absence of cellulose in these residues (Gassara et al. 2010). The study of Gassara et al. (2010) on the production of ligninolytic enzymes using fishery residues might offer an impetus for further research in this field. Nevertheless, other microbial strains should be tested using various fish processing wastes as growth media taking into consideration various factors (waste composition, the microbial strains, the strain nutrient requirements, fermentation parameters, etc.).

\section{Conclusions}

The disposal of wastes generated by fishery processing industries represents an increasing environmental and health problem. However, these by-products have attracted considerable attention as an alternative feedstock and energy source, since they are abundantly available. Various microbes are capable of using these substances as carbon and energy sources beneficial in enzyme production process. A number of such substrates have been tested for the cultivation of microorganisms to produce several enzymes (protease, lipase, chitinases, peroxidases, laccases, oxidases, etc.). This may have numerous advantages for enzyme production process, such as superior productivity, simpler techniques, reduced energy requirements and reduced production costs. Generally, fish waste pre-treatments may be necessary to maximize microbial growth and enzyme production. However, each microbial strain has its own special conditions for maximum enzyme production. Therefore, it is of great significance to optimize the medium composition, taking into consideration the variability of fish waste composition, the nutrient requirements of microbial strain and fermentation parameters $(\mathrm{pH}$, temperature, aeration, agitation, etc.). Nevertheless, the improvements in fish waste technology (pre-treatments, characterization, formulation, etc.) are still necessary before large-scale application of this new strategy can be realized.

Conflict of interest The authors declare that they have no conflict of interest.

Open Access This article is distributed under the terms of the Creative Commons Attribution License which permits any use, distribution, and reproduction in any medium, provided the original author(s) and the source are credited.

\section{References}

Awarenet (2004) Handbook for the prevention and minimization of waste and valorization of by-products in European agro-food industries. Agro-food waste minimization and reduction network (AWARENET). Grow Programme, European Commission, pp 1-7

Banerjee UC, Agnihotri R, Bhattacharyya BC (1993) Purification of alkaline protease of Rhizopus oryzae by foam fractionation. Bioprocess Eng 9:245-248

Banik RM, Prakash M (2004) Laundry detergent compatibility of the alkaline protease from Bacillus cereus. Microbiol Res 159:135-140

Bartolome B, Gomez-Cordoves C, Sancho AI, Diez N, Ferreira P, Soliveri J, Copa-Patino J (2003) Growth and release of hydroxycinnamic acids from brewer's spent grain by Streptomyces avermitilis CECT3339. Enzym Microb Technol 32: 140-144

Batista I (1999) Recovery of proteins from fish waste products by alkaline extraction. Eur Food Res Technol 210:84-89

Ben Rebah F, Frikha F, Kammoun W, Belbahri L, Gargouri Y, Miled N (2008) Culture of Staphylococcus xylosus in fish processing by-product-based media for lipase production. Lett Appl Microbiol 47:549-554

Birnbaum LS (1994) Endocrine effects of prenatal exposure to PCBs, dioxins, and other xenobiotics: implications for policy and future research. Environ Health Perspect 102:676-679

Blanco M, Sotelo CG, Chapela MJ, Perez-Martin RI (2006) Towards sustainable and efficient use of fishery resources: present and future trends. Trends Food Sci Technol 18:29-36 
Bozzano A, Sarda F (2002) Fishery discard consumption rate and scavenging activity in the northwestern Mediterranean Sea. ICES J of Mar Sci 59:15-28

Chang WT, Chen CS, Wang SL (2003) An antifungal chitinase produced by Bacillus cereus with shrimp and crab shell powder as a carbon source. Curr Microbiol 47:102-108

Chen CC, Chaung HC, Chung MY, Huang LT (2006) Menhaden fish oil improves spatial memory in rat pups following recurrent pentylenetetrazole-induced seizures. Epilepsy Behav 8:516-521

Coello N, Brito L, Nonus M (2000) Biosynthesis of L-lysine by Corynebacterium glutamicum grown on fish silage. Bioresour Technol 73:221-225

Dahiya N, Tewari R, Tiwari RP, Hoondal GS (2005) Production of an antifungal chitinase from Enterobacter sp. NRG4 and its application in protoplast production. World J Microbiol Biotechnol 21:1611-1616

Dahiya N, Tewari R, Hoondal GS (2006) Biotechnological aspects of chitinolytic enzymes: a review. Appl Microbiol Biotechnol 71:773-782

Danzo BJ (1997) Environmental xenobiotics may disrupt normal endocrine function by interfering with the binding of physiological ligands to steroid receptors and binding proteins. Environ Health Perspect 105:294-301

De Azeredo LAI, Freire DMG, Soares RMA, Leite SGF, Coelho RRR (2004) Production and partial characterization of thermophilic proteases from Streptomyces $s p$. isolated from Brazilian cerrado soil. Enzym Microb Technol 34:354-358

Ellouz Y, Bayoudh A, Kammoun S, Gharsallah N, Nasri M (2001) Production of protease by Bacillus subtilis grown on sardinelle heads and viscera flour. Bioresour Technol 80:49-51

Esakkiraj P, Immanuel G, Sowmya SM, Iyapparaj P, Palavesam A (2009) Evaluation of protease-producing ability of fish gut isolate Bacillus cereus for aqua feed. Food Bioprocess Technol 2:383-390

Esakkiraj P, Austin Jeba Dhas G, Palavesam A, Immanuel G (2010a) Media preparation using tuna-processing wastes for improved lipase production by shrimp gut isolate Staphylococcus epidermidis CMST Pi2. Appl Biochem Biotechnol 160:1254-1265

Esakkiraj P, Rajkumarbharathi M, Palavesam A, Immanuel G (2010b) Lipase production by Staphylococcus epidermidis CMST-Pi 1 isolated from the gut of shrimp Penaeus indicus. Ann Microbiol 60:37-42

Faid M, Zouiten A, Elmarrakchi A, Achkari-Begdouri A (1997) Biotransformation of fish waste into a stable feed ingredient. Food Chem 60:13-18

FAO (2007) La situation mondiale des pêches et de l'aquaculture 2006. Département des pêches et de l'aquaculture, Rome

Frost GM, Moss DA (1987) Production of enzymes by fermentation. In: Rehm HJ, Reed G, Kennedy JF (eds) Biotechnology. vol 7a, VCH, Weinheim, pp 65-211

Fujiwara N, Yamamoto K (1987) Decomposition of gelatin layers on $\mathrm{X}$-ray films by the alkaline protease from Bacillus sp. Hakkokogaku 65:531-534

Gao MT, Hirata M, Toorisaka E, Hano T (2006) Acid-hydrolysis of fish wastes for lactic acid fermentation. Bioresour Technol 97:2414-2420

Gassara F, Brar SK, Tyagi RD, Verma M, Surampalli RY (2010) Screening of agro-industrial wastes to produce ligninolytic enzymes by Phanerochaete chrysosporium. Biochem Eng J 49:388-394

Ghorbel S, Soussi N, Ellouz YT, Duffosse L, Guerard F, Nazri M (2005) Preparation and testing of Sardinella protein hydrolysate as nitrogen source for extracellular lipase production by Rhizopus oryzae. World J Microbiol Biotechnol 21:33-38

Gupta R, Beg QK, Khan S, Chauhan B (2002) An overview on fermentation, downstream processing and properties of microbial alkaline proteases. Appl Microbiol Biotechnol 60:381-395
Gupta R, Gupta N, Rathi P (2004) Bacterial lipases: an overview of production, purification and biochemical proprieties. Appl Microbiol Biotechnol 64:763-781

Hacking AJ (1987) Economic aspects of biotechnology. Cambridge University Press, Cambridge, p 317

Haddar A, Fakhfakh-Zouari N, Hmidet N, Frikha F, Nasri M, SellamiKamoun A (2010) Low-cost fermentation medium for alkaline protease production by Bacillus mojavensis A21 using hulled grain of wheat and Sardinella peptone. J Biosc Bioeng 110:288-294

Hasan F, Shah AA, Hameed A (2006) Industrial applications of microbial lipases. Enzym Microb Technol 39:235-251

Hassan TE, Heath JL (1986) Biological fermentation of fish waste for potential use in animal and poultry feeds. Agric Wastes 15:1-15

Itoh Y, Kawase T, Nikajdou N, Fukada H, Mitsutomi M, Watanabe T, Itoh Y (2002) Functional analysis of the chitin binding domain of a family 19 chitinase from Streptomyces griseus HUT6037: substrate-binding affinity and cis-dominant increase of antifungal function. Biosci Biotechnol Biochem 66:1084-1092

Jacob N, Prema P (2006) Influence of mode of fermentation on production of polygalacturonase by a novel strain of Streptomyces lydicus. Food Technol Biotechnol 44:263-267

Joo HS, Chang CS (2005) Production of protease from a new alkalophilic Bacillus sp I-312 grown on soybean meal: optimization and some properties. Proc Biochem 40:1263-1270

Kacem M, Sellami M, Kammoun W, Frikha F, Miled N, Ben Rebah F (2011) Seasonal variations of chemical composition and fatty acid profiles of viscera of three marine species from the Tunisian coast. J Aquat Food Prod Technol 20:233-246

Karim AA, Bhat R (2009) Fish gelatin: properties, challenges, and prospects as an alternative to mammalian gelatins. Food Hydrocolloids 23:563-576

Kim SK, Mendis E (2006) Bioactive compounds from marine processing by-products-a review. Food Res Int 39:383-393

Kim YJ, Kim HJ, No JK, Chung HY, Fernandes G (2006) Antiinflammatory action of dietary fish oil and calorie restriction. Life Sci 78:2523-2532

Kirk TK, Farrell RL (1987) Enzymatic "combustion": the microbial degradation of lignin. Annu Rev Microbiol 41:465-501

Krieg RN, Holt JG (1984) Bergey's manual of systematic Bacteriology, vol 1. Williams and Wilkins Company, Baltimore, USA, pp 308-429

Kumar CG, Takagi H (1999) Microbial alkaline proteases from a bioindustrial viewpoint. Biotechnol Adv 17:561-594

Liang TW, Lin JJ, Yen YH, Wang CL, Wang SL (2006) Purification and characterization of a protease extracellularly produced by Monascus purpureus CCRC31499 in a shrimp and crab shell powder medium. Enzym Microb Technol 38:74-80

Liao PH, Jones L, Lau AK, Walkemeyer S, Egan B, Holbek N (1997) Composting of fish wastes in a full-scale in-vessel system. Bioresour Technol 59:163-168

Liaset BD, Lied E, Espe M (2000) Enzymatic hydrolysis of byproducts from the fish-filleting industry; chemical characterisation and nutritional evaluation. J Sci Food Agric 80:581-589

Ma C, Ni X, Chi Z, Ma L, Gao L (2007) Purification and characterization of an alkaline protease from the marine yeast Aureobasidium pullulans for bioactive peptide production from different sources. Mar Biotechnol 9:343-351

Martone CB, Borla OP, Sanchez JJ (2005) Fishery by-product as a nutrient source for bacteria and archaea growth media. Bioresour Technol 96:383-387

Matsumoto Y, Revah S, Saucedo G, Hall GM, Shirai K (2001) Chitinases production in solid state fermentation of shrimp waste silage. In: Muzzarelli RAA (ed) Chitin enzymology. Atec Edizioni, Italy, pp 381-389

Matsumoto Y, Saucedo-Castaneda G, Revah S, Shirai K (2004) Production of $\beta$ - $N$-acetylhexosaminidase of Verticillium lecanii

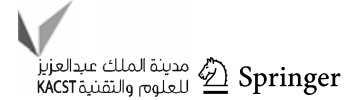


by solid state and submerged fermentations utilizing shrimp waste silage as substrate and inducer. Process Biochem 39:665-671

Miyashita K, Fujii T, Sawada Y (1991) Molecular cloning and characterization of chitinase gene from Streptomyces lividans. J Microbiol 137:2065-2072

Oh YS, Shih IL, Tzeng YM, Wang SL (2000) Protease produced by Pseudomonas aeruginosa K-187 and its application in the deproteinization of shrimp and crab shell wastes. Enzym Microb Technol 27:3-10

Okazaki K, Kato F, Watanabe N, Yasuda S, Masui Y, Hayakawa S (1995) Purification and properties of two chitinases from Streptomyces sp. J-13-3. Biosci Biotechnol Biochem 59:1586-1587

Palaniyappan M, Vijayagopal V, Renukal V, Viswanathan R, Viruthagiri $T$ (2009) Screening of natural substrates and optimization of operating variables on the production of pectinase by submerged fermentation using Aspergillus niger MTCC 281. Afr J Biotechnol 8:682-686

Pandey A, Selvakumar P, Soccol CR, Nigam P (1999) Solid state fermentation for the production of industrial enzymes. Curr Sci $77: 149-162$

Park JK, Morita K, Fukumoto I, Yamasaki Y, Nakagawa T, Kawamukai M, Matsuda H (1997) Purification and characterization of the chitinase (ChiA) from Enterobacter sp. G-1. Biosci Biotechnol Biochem 61:684-689

Roberts DP, McKenna LF, Lakshman DK, Meyer SLF, Kong H, Souza JT, Lydon J, Baker CJ, Buyer JS, Chung S (2007) Suppression of dumping-off of cucumber caused by Pythium ultimum with live cells and extracts of Serratia marcescens N4-5. Soil Biol Biochem 39:2275-2288

Rodríguez S, Toca JL (2006) Industrial and biotechnological applications of laccases: a review. Biotechnol Adv 24:500-513

Rubio-Rodriguez N, Beltran S, Jaime I, de Diego SM, Sanz MT, Carballido JR (2010) Production of omega-3 polyunsaturated fatty acid concentrates: a review. Innov Food Sci Emerg Technol 11:1-12

Ruiz-Duenas FJ, Martinez AT (2009) Microbial degradation of lignin: how a bulky recalcitrant polymer is efficiently recycled in nature and how we can take advantage of this. Microb Biotechnol 2:164-177

Sharma R, Chisti Y, Banerjee UC (2001) Production, purification, characterization and applications of lipases. Biotechnol Adv 19:627-662

Shen KT, Chen MH, Chan HY, Jeng JH, Wang YJ (2009) Inhibitory effects of chitooligosaccharides on tumor growth and metastasis. Food Chem Toxicol 47:1864-1871

Shirai K, Guerrero I, Huerta S, Saucedo G, Castillo A, Gonzalez RO, Hall GM (2001) Effect of initial glucose concentration and inoculation level of lactic acid bacteria in shrimp waste ensilation. Enzym Microb Technol 28:446-452

Souissi N, Ellouz-Triki Y, Bougatef A, Blibech M, Nasri M (2008) Preparation and use of media for protease-producing bacterial strains based on by-products from Cuttlefish (Sepia officinalis) and wastewaters from marine-products processing factories. Microbiol Res 163:473-480

Suetsuna K (2000) Antioxidant peptides from the protease digest of prawn (Penaeus japonicus) muscle. Mar Biotechnol 2:5-10

Suzuki K, Sugawara N, Suzuki M, Uchiyama T, Katouno F, Nikaidou N, Watanabe T (2002) Chitinases, A, B and C1 of Serratia marcescens 2170 produced by recombinant $E$. coli: enzymatic properties and synergism on chitin degradation. Biosci Biotechnol Biochem 66:1075-1083

Takayanagi T, Ajisaka K, Takiguchi Y, Shimahara K (1991) Isolation and characterization of thermostable chitinases from Bacillus licheniformis X-74. Biochim Biophys Acta 1078:404-410
Taylor MM, Bailey DG, Feairheller SH (1987) A review of the use of enzymes in the tannery. J Am Leather Chem Assoc 82:153-165

Toppe J, Albrektsen S, Hope B, Aksnes A (2007) Chemical composition, mineral content and amino acid and lipid profiles in bones from various fish species. Comp Biochem Physiol B 146:395-401

Triki-Ellouz Y, Ghorbel B, Souissi N, Kammoun S, Nasri M (2003) Biosynthesis of protease by Pseudomonas aeruginosa MN7 grown on fish substrate. World J Microbiol Biotechnol 19:41-45

Tsai GI, Wu ZY, Su WH (2000) Antibacterial activity of a chitooligosaccharide mixture prepared by cellulose digestion of shrimp chitosan and its application to milk preservation. J Food Prot 63:747-752

Ueda M, Fujiwara A, Kawaguchi T, Arai M (1995) Purification and some properties of six chitinases from Aeromonas sp. No. 10S24. Biosci Biotechnol Biochem 59:2162-2164

Underkofler LA, Barton RR, Rennert SS (1958) Microbial process report: production of microbial enzymes and their applications. Appl Microbiol 6:212-221

Vazquez JA, Gonzalez MP, Murado MA (2004) A new marine medium - use of different fish peptones and comparative study of the growth of selected species of marine bacteria. Enzyme Microb Technol 35:385-392

Vazquez JA, Docasal SF, Miron J, Gonzalez MP, Murado MA (2006) Proteases production by two Vibrio species on residuals marine media. J Ind Microbiol Biotechnol 33:661-668

Vazquez JA, Docasal SF, Prieto MA, Gonzalez MP, Murado MA (2008) Growth and metabolic features of lactic acid bacteria in media with hydrolysed fish viscera. An approach to bio-silage of fishing by-products. Bioresour Technol 99:6246-6257

Vendruscolo F, Albuquerque PCM, Streit F, Esposito E, Ninow JL (2008) Apple pomace: a versatile substrate for biotechnological applications. Crit Rev Biotechnol 28:1-12

Wang SL, Chang WT (1997) Purification and characterization of two bifunctional chitinases/lysozymes extracellularly produced by Pseudomonas aeruginosa K-187 in shrimp and crab shell powder medium. Appl Environ Microbiol 63:380-386

Wang SL, Yeh PY (2006) Production of a surfactant- and solventstable alkaliphilic protease by bioconversion of shrimp shell wastes fermented by Bacillus subtilis TKU007. Process Biochem 41:1545-1552

Wang SL, Yeh PY (2008) Purification and characterization of a chitosanase from a nattokinase producing strain Bacillus subtilis TKU007 using shrimp shell powder as a medium. Process Biochem 43:132-138

Wang SL, Chang WT, Lu MC (1995) Production of chitinase by Pseudomonas aeruginosa K-187 using shrimp and crab shell powder as a carbon source. Proc Natl Sci Counc ROC B 19:105-112

Wang SL, Shih IL, Liang TW, Wang CH (2002a) Purification and characterization of two antifungal chitinases extracellularly produced by Bacillus amyloliquefaciens V656 in a shrimp and crab shell powder medium. J Agric Food Chem 50:2241-2248

Wang SL, Hsiao WJ, Chang WT (2002b) Purification and characterization of an antimicrobial chitinases extracellularly produced by Monascus purpureus CCRC31499 in a shrimp and crab shell powder medium. J Agri Food Chem 50:2249-2255

Wang SL, Kao TY, Wang CL, Yen YH, Chern MK, Chen YH (2006a) A solvent stable metalloprotease produced by Bacillus sp. TKU004 and its application in the deproteinization of squid pen for $\beta$-chitin preparation. Enzym Microb Technol 39:724-731

Wang SL, Lin TY, Yen YH, Liao HF, Chen YJ (2006b) Bioconversion of shellfish chitin wastes for the production of Bacillus subtilis W-118 chitinase. Carbohydr Res 341:2507-2515

Wang SL, Huang TY, Wang CY, Liang TW, Yen YH, Sakata Y (2008a) Bioconversion of squid pen by Lactobacillus paracasei 
subsp paracasei TKU010 for the production of proteases and lettuce growth enhancing biofertilizers. Bioresour Technol 99:5436-5443

Wang SL, Hsu WT, Yen YH, Wang CL (2008b) Purification and characterization of three novel keratinolytic metalloproteases produced by Chryseobacterium indologenes TKU014 in a shrimp shell powder medium. Bioresour Technol 99:5679-5686

Wang SL, Wang CY, Huang TY (2008c) Microbial reclamation of squid pen for the production of a novel extracellular serine protease by Lactobacillus paracasei subsp. paracasei TKU012. Bioresour Technol 99:3411-3417

Wang SL, Chen SJ, Wang CL (2008d) Purification and characterization of chitinases and chitosanases from a new species strain Pseudomonas sp. TKU015 using shrimp shells as a substrate. Carbohydr Res 343:1171-1179

Wang SL, Pen JH, Liang TW, Liu KC (2008e) Purification and characterization of a chitosanase from Serratia marcescens TKU011. Carbohydr Res 343:316-1323

Wang SL, Lin CL, Liang TW, Liu KC, Kuo YH (2009a) Conversion of squid pen by Serratia ureilytica for the production of enzymes and antioxidants. Bioresour Technol 100:316-323

Wang SL, Chao CH, Liang TW, Chen CC (2009b) Purification and characterization of protease and chitinase from Bacillus cereus TKU006 and conversion of marine wastes by these enzymes. Mar Biotechnol 11:334-344

Wang SL, Liou JY, Liang TW, Liu KC (2009c) Conversion of squid pen by using Serratia sp. TKU020 fermentation for the production of enzymes, antioxidants, and $N$-acetyl chitooligosaccharides. Process Biochem 44:854-861
Wang SL, Chen TR, Liang TW (2009d) Conversion and degradation of shellfish wastes by Bacillus cereus TKU018 fermentation for the production of chitosanase and bioactive materials. Biochem Eng J 48:111-117

Wang SL, Wu PC, Liang TW (2009e) Utilization of squid pen for the efficient production of chitosanase and antioxidant through prolonged autoclave treatment. Carbohydr Res 344:979-984

Wang SL, Chang TJ, Liang TW (2010) Conversion and degradation of shellfish wastes by Serratia sp. TKU016 fermentation for the production of enzymes and bioactive materials. Biodegradation 21:321-333

Wang SL, Liang TW, Yen YH (2011) Bioconversion of chitincontaining wastes for the production of enzymes and bioactive materials. Carbohydr Polym 84:732-742

Wen CM, Tseng CS, Cheng CY, Li YK (2002) Purification, characterization and cloning of a chitinase from Bacillus sp. NCTU2. Biotechnol Appl Biochem 35:213-219

Xu W, Yu G, Xue C, Xue Y, Ren Y (2008) Biochemical changes associated with fast fermentation of squid processing byproducts for low salt fish sauce. Food Chem 107:1597-1604

Yamamoto M, Saleh F, Ohtsuka A, Hayashi K (2005) New fermentation technique to process fish waste. Anim Sci J 76:245-248

Yano Y, Oikawa H, Satomi M (2008) Reduction of lipids in fish meal prepared from fish waste by a yeast Yarrowia lipolytica. Int $\mathbf{J}$ Food Microbiol 121:302-307

Zampolli A, Bysted A, Leth T, Mortensen A, De Caterina R, Falk E (2006) Contrasting effect of fish oil supplementation on the development of atherosclerosis in marine models. Atherosclerosis $184: 78-85$ 